\title{
Tribal Proclivity and its Effects on the Cooperate Existence of Nigeria in the Centenary Era: An Islamic Perspective
}

\author{
USMAN JIMOH MUHAMMAD ${ }^{1}$
}

\begin{abstract}
The paper consists of seven sub-sections namely, the introduction, a flash on the prevalence of tribal proclivity in Nigeria, causes of tribal proclivity among Nigerians and its effects. Other aspect of the paper includes the Islamic perspective on tribal proclivity in Nigeria, recommendations and conclusion. The introduction briefly appraises the historical composition of Nigeria in the early nineteen century and its amalgamation in the year 1914. Reference is being made in the paper to cases of tribal proclivity in Nigeria while the causes of tribal penchant include unemployment, selfishness of some politicians, lack of patience and endurance by citizens in their relationship among themselves. Tribal proclivity the paper affirms results into insecurity of lives and properties, portrays evidence of lack of unity and bad governance. The paper examines some relevant verses and prophetic traditions in a bid to redress the situation and recommends that the government and the well to problem of unemployment in the nation. In addition, religious do people in the society should join hands together towards addressing the scholars and other orientation bodies must reorient people towards peaceful coexistence among themselves.
\end{abstract}

Keywords: ethnicism, history of Nigeria, Islam and tribalism, tribal proclivity

The word tribal is an adjective describing the noun tribe. Tribal is synonymous to the word, ethnic, family ancestral etc. Proclivity on the other hand is also synonymous to tendency inclination, or penchant. It entails the natural tendency to behave in a particular way. Tribal proclivity from the above entails the act of being inclined to tribal feelings or exhibition of the act of tribalism. In one of the Prophetic traditions, Prophets s.a.w provides an insight as to the concept of tribalism: "It was narrated from the daughter of Wathilah bin Al-Asqa' that she heard her father say: I said: ' $O$ Messenger of Allah what is tribalism? He said. When you help your people in wrongdoing" (Abu Dawud 2007). The expression tribal proclivity and its effects on the cooperate existence of Nigeria in the centenary era therefore symbolises how the concept of tribalism affects the continuous existence of Nigeria as it attains a hundred years of emergence. The topic is equally viewed from the Islamic point of view. A cursory look at the early history of the territory of the Federal Republic of Nigeria especially from the nineteenth century reveals that this region encompasses a number of independent empires and kingdoms. In addition, each of these enclaves has its own peculiar traditions, customs and institutions. Prominent among the enclaves are the Sokoto caliphate in the North, the Oyo Empire in the South Western region, the Igbo people in the eastern part and the Benin Empire. Borno Empire also existed and is situated in the North eastern part of the present day Nigeria.

\footnotetext{
1 Usman Jimoh Muhammad, Ph.D., lecturer at Department of Islamic Studies, Federal University of Education, ZARIA, Kaduna State, Nigeria, email: mujnar@yahoo.com.
} 
Furthermore, with passage of time, the British in their bid to secure more colonies, embarked on penetration of these areas of land. Oke (2007) holds that in furtherance of their influence on the present day Nigeria, on the $1^{\text {st }}$ January, 1914, the Northern and Southern part of Nigeria were amalgamated together to form a colony and protectorate called Nigeria. This protectorate was then governed by Fredick Lugard as the first governor of the country. This was also done purposely to ease the act of governance of the two areas in the interest of the British government. Inferentially, the year (2014) marks a centenary in the history of formation of the country Nigeria. Having traverse through a number of distance, it is quite apt to flash back memory with the intent of appraising the past so as to redress the wrongs in the nearest future. Among the pertinent issue that needs to be addressed is the effect of tribalism on the cooperate existence of the Nigerian nation as it attains a hundred years of unification. Bambose (1971), in his submission avows that the country has over 400 to 420 ethnic groups. This however could not be viewed as a factor that could hinder the continual existence of the Country as a Nation. Moreover, there are about 645 distinctive ethnic groups in India and all of them exist under only a country called India.

\section{A Flash on the Prevalence of Tribal Proclivity in Nigerian}

One open truth is that, since the amalgamation of the Northern and Southern protectorate together in 1914, there had been series of exhibition of tribal inclination by Nigerians in their relations among themselves. Coleman (1958) testifies to the prevalence of ethnic prejudice among the three major ethnic groups in Nigeria in the 1940s. Popoola (2014), affirms that the need to foster unity among the various ethnic groups of the nation was one of the conceived idea behind the amalgamation of the country in 1914. The attainment of this he upholds remains a mirage due to a number of tribal conflicts witnessed in the country from time to time. According to Robin (1971), the 1966 coup and counter coup for example, insinuated in the hearth of the people some tribal feelings and ethnic predilection. The coup plotters were mostly from a particular ethnic group of the country (Igbo). In addition, the coup claimed twenty seven lives of which the casualties were mostly from the other ethnic groups of the nation. Of all the civilians killed, none was an Igbo or from the East. The Premier of the North who represents mostly the Hausa- Fulani and other ethnic groups within the region, the Premier of the West who was the representative of the Yoruba people and other ethnic group within the region, and the Federal Prime Minister, Sir Tafawa Balewa also a Northerner were all massacred. The Igbo Premiers of the East and Midwest in person of M. I. Okpara and D.C. Osadebe respectively were both safe and secure in this travail. Furthermore, four (4) out of the five massacred, military officers of the ranks of Lt. Colonel and above were Northerners (Hausa- Fulani and others). Other figures also reveal that while the Igbo people were safe, loses secured by the Hausa-Fulani people and the Yoruba people are noteworthy.

Okwudiba (1978) affirms that out of the seven Army Majors who participated actively in the plotting and executing of the coup, six belong to the same ethnic group. Similarly, nineteen out of another rank of twenty three officers who were involved in this mayhem also belong to the same ethnic group (the Igbo/South East people). In an attempt to daunt the tension, in May 1967, the Head of State General Yakubu Gowon, was bent towards creation of twelve states from the existing four regional governments. This idea did not go well with the former Eastern Region Governor, Lt. Col. Ojukwu who later decided to declare the Region as an independent state of Biafra. For example, the emergence of some ethnically motivated associations in Nigeria further accentuates the prevalence of ethnic penchant in Nigeria. Adoke (2008) opines that the emergence of the movement for the mass actualisation of the sovereign state of Biafra MASSOB, 
the Oduduwa progressive council (OPC), the Arewa people's congress (APC) are all evidences of inclination of Nigerians towards tribal proclivity.

Dopamu (2010) substantiates on this as he makes few illustration on some ethno religious conflict in Nigeria. Practical examples of this he argues are the Jos ethno-religious conflict of $8^{\text {th }}-9^{\text {th }}$ September 2000 and its reoccurrence in November, 2008 and the Tiv-Jukum, ethno-religious crises of October 2001 in Taraba state. Similarly, Ango (2001) validates the inclination of Nigeria to tribalism with reference to the clashes between the Jukum-Tiv people of Taraba state. Adoke (2008) affirms that the reoccurrence of Yoruba- Hausa clashes as a good example of exhibition of tribal predilection among Nigerians in their relationship among themselves. This mind set, according to Adoke (2008) prompts the Odua People Congress (OPC) and the Hausa community clashes in October 2000 and the Ijaw-Itsekiri's war in Warri. Badsha \& Turaki (2013) in one of the Nigerian dailies write that the Controller General of the Custom Service, MRS Rose Uzoma was accused of favouring his kinsmen from the Southeast in the distribution of the vacancies available in the service. The report of house committee on Federal character commission which unravels this erroneous act equally attests that out of the 25,000 immigration staff in the country, Imo state has the highest number totalling 1190 Sokoto State has the least of 200. She was also reported to have favoured some top wigs of the government and their relatives with certain slots. This development prompted her removal in by the President in 2013. There are some causes of tribal proclivity among Nigerians.

\section{Unemployment}

An idle mind a popular aphorism affirms is an evil mind. The rate of unemployment in Nigerian is alarming as thousands of graduate are annually discharged into the labour market to scramble for the few places available in the society. This youth are easily bent to violence whenever two tribal groups engage in conflict in the society. This chaotic environment avails them the chance to loot peoples' properties in an attempt to survive. While relating the level of poverty in Nigeria as at 2007, Kolapo (2007) reports that $81.8 \%$ of the populace of the North East lives in poverty, $71.9 \%$ in the North West,80.0 \% in the North Central, $77.6 \%$ in the South East, $74.85 \%$ in the South-South and $71.5 \%$ in the South West all live in poverty. Similarly, in the same year, Olu (2007) reports that the Director General of the National Directorate of Employment testified to the fact that about two hundred thousand graduates with their respective NYSC certificates issued five years ago are unemployed. The Gender report of the year 2012 clearly attests to the fact that Nigeria is the giant of African and accounts for about 162.5 million people. Out of this figure, 54\% lives under the poverty level. Ideyi \& Isijola (2007) also agree that poverty is one of the major causes of ethno-religious conflict in Nigeria. This poses a threat to the cooperate existence of Nigeria.

\section{Selfishness of Some Political Leaders}

Politics in Nigeria is being manipulated by some selfish politicians to achieve their desire goals. This makes them to embark on campaign based on tribal sentiment in order to achieve their political mission. This is a calculated measure embarked on by these politicians when all other factors failed to accord them a better chance in their political ambition. This often results into crises where people of different ethnic background raise arms against one another. 


\section{The Belief on Tribal Proclivity at All Cost}

Some people are strict on being total loyalist to their tribal instinct and as such ready to fight other ethnic group without due recourse to moral rectitude. This kind of belief no doubt helps not the situation as it gives room for marginalisation based on tribal instinct and a times result into communal clash. Consequently, it promotes the spirit of hostility at the expense of the cooperate existence of the nation.

\section{Denigration of the Cultural and Religious Beliefs and Practices of the People}

In Nigeria for example, cultural and religious belief and practices of the people are given high level of veneration. This implies that any attempt to belittle them is met with great confrontation. Unfortunately some Nigerians do not give cognisance to this in their relations with people of other ethnic groups. When a cultural belief or practice of an ethnic group is denigrated by any other ethnic group, it results into rift and cleft between the two groups. The same applies to religious and cultural beliefs and practices.

\section{Intemperate Utterances and Actions}

Some tribal mayhem are borne out of the inability of two or more ethnic group to embrace the spirit of patience and endurance in their relations among themselves. This scenario paves way for the occurrence of tribal pandemonium based on trivial issues. According to Coleman (1958), in the 1940s, the intemperate utterances of Nnamdi Azikwe a famous Igbo leader against the Hausa and Yoruba ethnic groups of Nigeria propagated the spirit of ethnic chauvinism. He used his journalistic skills to portray them badly in the public. This scenario created a kind of resentment against Nnamdi Azikwe and equally affected other members of his ethnic group who were sympathetic with him.

\section{Historical Antecedent and Superiority Contest}

Transmission of historical relations of incident of past hostility between two ethnic groups often spur the later generation into the act of vengeance and retribution. When this happen people who have agreed to live together as a nation are made to race arms against one another. The belief in the superiority of a tribe over the other if not checkmated stimulates a kind rift between the two. Unnecessary competition among people, this does not urge well for the cooperate existence of the nation.

\section{Effects of Tribal Proclivity}

Conflicts and clashes pose great threat to security of life and properties whenever they occur in a society. Popoola (2014) validates this assertion with particular reference to the lots of lives and properties destroyed due to relocation from the war zone to a safety region during instances of a 'tribal conflicts between the major tribes in Nigeria (Hausa, Yoruba and Igbo.) In the same vein, Babawale (2003) opines that many tribal conflicts have resulted into the destruction of telecommunication equipments, electrical installations and petroleum pipelines. Adoke (2008) also reiterates on the lives and properties that were lost in the tragedy of the year 2000 where the Yoruba people clashed with the resident community of Hausa in Sagamu. This does not auger well for the unity of the country. 
Although Nigeria has been able to sustain itself from disintegration since a century ago, what remains the future of the nation is no doubt uncertain. This is borne out of evidence of lack of unity among the diverse ethnic groups. The records of ethnic conflict and reports of marginalisation of an ethnic group by the other pose great challenge to the cooperate existence of the country. With the engrossment of people in the act of tribal proclivity, resources are likely to be allocated by leaders based on tribal penchant. This kind of attitude hinders good governance and promotes economic setback for the nation. In addition, it enhances the proliferation of hostility between the marginalised community and the favoured society by the leaders thereby threatening the cooperate existence of the nation.

Tribal proclivity had grown wings to the extent where people could sacrifice values for iniquity. For example, Bello (2013) narrates the case of the former Aviation Minister, Ms. Stella Oduah, who was involved in the purchase of the most expensive bullet proof vehicles- BMW 760 Li HSS. This was done at an anomalous price of N255m (\$1.6m) through the Nigerian Civil Aviation Authority (NCAA). This incident was seriously condemned by a vast majority of Nigerians, both at home and abroad. In addition, this act of profligacy made people to call for her expulsion from her seat. This was a clear case of corruption and betrayal of trust by the Minister. Unfortunately, a group, called the 'Igbo Progressive Union (IPU), according to the Punch newspaper published on October 27, 2013, protested in defence of the Minister on the basis of tribal proclivity. This behaviour is not peculiar to the Igbo people as the same is applicable to the Hausa and Yoruba ethnic group in Nigeria.

\section{Islamic Perspective on Tribal Proclivity in Nigeria}

Islam kicks against the act of tribal inclination as it was practiced in the pre-Islamic era. There are many prophetic traditions condemning the act of tribal penchant. The following are few illustrations:

It was narrated from 'Abdur-Rahman bin 'Abdullah bin Mas'ud, that his father said: "Whoever supports his people on a basis other than the truth, he is like a camel that falls into a well and is pulled out by its tail (Abu Dawud 2007).

It was narrated from Jubair bin Mut'im, that the Messenger of Allah said: "He is not one of us who promotes tribalism he is not one of us who fights for the sake of tribalism; he is not one of us who dies following the way of tribalism (Abu Dawud 2007).

Syed (2008) expresses the Islamic point of view of Islam on tribal proclivity as he says:

Islam rejects the kind of group feeling, which is similar to the one prevalent during the pre-Islamic period, which protects injustice or makes man arrogant or for the gratification of human desires and wasteful activities. Similar to his position on royal authority, he says that 'when the religious law censures group feeling, it is directed against a group feeling that is used for worthless purposes as was in the case in pre-Islamic times. It is also directed against a group feeling that makes a person proud and superior. 
To address the Nigeria situation efforts needs to be exalted towards remedying the causes of tribal predilection so as to avert its effect. The problem of unemployment must be addressed so that the unemployed youth could be saved from being handiwork of the devil. Usman (2013) buttresses that the institution of Zakat (9:60) is meant to alleviate poverty from the society and as such should be embraced by people so that the problem of unemployment could be addressed and poverty ridden reduced in the society. In Islam, the rich are expected to take care of the less privileged ones in the society. It is to this effect that the later was apportioned a right in the wealth of the former as the Glorious Quran says: "And in their wealth and possessions [was remembered] the right of the [needy,] him who asked, and him who [for some reason] was prevented [from asking] (51:19). Prophet also put in place principles meant to address the plight of the poor class of the society: "It was narrated from Abu Yasar, the Companion of the Prophet that the Messenger of Allah said: Whoever would like Allah to shade him with His shade, let him give respite to one in difficulty, or waive repayment of the loan" (Ibn Majah n.d.).

Islam encourages Muslims to embrace the spirit of sincerity and put aside the culture of self-centredness. The attainment of peaceful coexistence among the diverse ethnic groups in the country, hinges on exhibition of the spirit of justice by the leaders and the led. To avert all forms of tribal insinuation, leaders must jettison all prejudice and deal with citizen base on equal ground. The Glorious Quran says:

0 ye who believe! stand out firmly for justice, as witnesses to Allah, even as against yourselves, or your parents, or your kin, and whether it be [against]rich or poor: for Allah can best protect both. Follow not the lusts [of your hearts], lest ye swerve, and if ye distort [justice] or decline to do justice, verily Allah is wellacquainted with all that ye do (4:135).

And when ye judge between man and man that ye judge with justice: Verily how excellent is the teaching which He giveth you! For Allah is He Who heareth and seeth all things (4:58).

In view of the above, politicians must be sincere in the course of their political mission so that the division of Nigerians base on tribal feelings could be avoided. In the pre-Islamic era, the Arabs were accustomed to a popular tradition which requires a brother to render assistance to his fellow brother be him the oppressor or the oppressed. This made it easy for promotion of tribal feuds among them as people were not out to redress oppression but rather to promote tyranny and entrench subjugation of the people. The aforementioned pre-Islamic tradition is similar to what obtains among the diverse ethnic group groups in Nigeria. The following prophetic tradition settled scores among the Arabs as it prevented the proliferation of tyranny and promotes abnegation of oppression irrespective of the person involved:

Narrated Anas May Allah be pleased with him: Allah's Messenger said, "Help your brother, whether he is an oppressor or he is an oppressed one. People asked, "O Allah's Messenger! It is all right to help him if he is oppressed, but how should we help him if he is an oppressor?" The Prophet said, "By preventing him from oppressing others" (Bukhari 1997). 
The above remedy to tribal feuds among Arabs could be of great importance in addressing the Nigerian situation. Moreover the Glorious Quran enjoins people to embrace the spirit of cooperation as it says: And cooperate in righteousness and piety, but do not cooperate in sin and aggression (5:2). Moreover, a popular aphorism holds that united we stand divided we fall. Superiority contest is seriously frowned at in Islam as Allah says:

0 mankind! Lo! We have created you male and female, and have made you nations and tribes, that ye may know one another. Lo! the noblest of you in the sight of Allah, is the best in conduct (49:13).

Islam discourages all forms of bad governance as it poses impedes the spirit of peaceful coexistence among people in the society. The following prophetic tradition is vital in this respect.

Narrated Ma'qil: I heard the Prophet ii saying, "Any man whom Allah has given the authority of ruling some people and he does not look after them in an honest manner, will never have even the smell of Paradise" (Bukhari (1997).

If any ruler having the authority to rule Muslim subjects dies while he is deceiving them, Allah will forbid Paradise for him (Bukhari 1997).

Whoever does a good deed in order to show off, Allah will expose his intentions on the Day of Resurrection (before the people), and whoever puts the people into difficulties, Allah will put him into difficulties on the Day of Resurrection (Bukhari 1997).

Among the aftermath effect of tribal feud is lost of lives. A severe punishment is attributed to the act of being responsible for lost of a soul as the Glorious Quran, Allah says:

On that account: We ordained for the Children of Israel that if any one slew a person--unless it be for murder or for spreading mischief in the land -it would be as if he slew the whole people: And if any one saved a life, it would be as if he saved the life of the whole people. Then although there came to them Our Apostles with Clear Signs, yet, even after that, many of them continued to commit excesses in the land (5:32).

The earth and the things therein belong to Allah as the Quran says; To Allah belong all things in the heavens and on earth (4:131). Whichever part of the country one happened to find himself, Islam requires that both the resident community and the indigenous citizens should consider themselves as neighbours and live peacefully among themselves. Tribal prejudice or religious penchants therefore are not yardstick for goodness to neighbour preached by Islam but rather the entire society is viewed as being one. The following prophetic traditions further avow the need for kind treatment of neighbours irrespective of his tribal inclination or religious belief.

By Allah, he does not believe! By Allah, he does not believe!" It was said, "Who is that, 0 Allah's Messenger?" He said, "That person whose neighbour does not feel safe from his evil" (Bukhari 1997). 
The spirit of good neighbourliness and true belief in Islam also hinge on respect for the dignity of fellow human being irrespective of his belief or tribal inclination. To ensure peaceful coexistence among people of diverse ethnic and religious groups in Nigeria, the Qur'anic teaching and prophetic tradition on regard for human dignity and respect for religious belief of others must be embraced. In the Glorious Quran, Allah s.w.t says: Revile not ye those whom they call upon besides Allah, lest they out of spite revile Allah in their ignorance (Quran 6:108).

0 ye who believe! Let not some men among you laugh at others: It may be that the [latter] are better than the [former]: Nor let some women laugh at others: It may be that the [latter are better than the [former]: Nor defame nor be sarcastic to each other, nor call each other by [offensive] nicknames: Ill seeming is a name connoting wickedness, [to be used of one] after he has believed: And those who do not desist are [indeed] doing wrong (65:11).

The following prophetic tradition also substantiates on the above as it says:

Narrated 'Abdur Rahman bin Abi Laila: Sahl bin Hunaif and Qais bin Sa'd were sitting in the city of Al-Qadisiya. A funeral procession passed in front of them and they stood up. They were told that that funeral procession was of one of the inhabitants of the land, i.e., of a disbeliever, under the protection of Muslims. They said, "A funeral procession passed in front of the Prophet and he stood up. When he was told that it was the coffin of a Jew, he said, "Is it not a human being? (Bukhari 1997).

In the above prophetic tradition, Prophet explains the significance of respect and regard for life and corpse of an unbeliever as he is among the human folk accorded regard by the creator. In the Glorious Quran, Allah says:

We have honoured the sons of Adam; provided them with transport on land and sea; given them for sustenance things good and pure; and conferred on them special favours, above a great part of our creation (17:70).

When mutual respect transpired among all the ethnic groups in Nigeria, stability of the nation is ensured and it's cooperate existence is guaranteed. From the foregoing, it is right to conclude that the cooperate existence of the Federal Republic of Nigeria in the future depends greatly on a number of factors. Prominent among them is the ability of the nation to address the problem of unemployment, reform the political mindset of the politicians towards putting the nation first in their political ambitions coupled with the readiness of the people to set aside tribalism and embrace the spirit of patriotism. Furthermore, mutual respect for the religious belief and practices of the people and the readiness of the people to embrace the spirit of perseverance all determine the cooperate existence of the Federal Republic of Nigeria in the years to come.

By the time a Yoruba man is courageous enough to bring back his fellow tribal man who had oppressed an Igbo man to the right track, by the time an Hausa-Fulani man is ready to do the same to his fellow tribal man who had oppressed a Yoruba man or by the time an Igbo man is valiant enough to oppose his tribal man in support of an oppressed Hausa-Fulani man all these as preached by Islam, the Nation could then be boastful of its cooperate existence in the future years. Therefore it is suggested that, the government and the well to do people in the 
Vol. 8: (Dec.) 2015

society should join hands together towards addressing the problem of unemployment in the nation. The leaders must set aside all forms of tribal proclivity and embrace the spirit of patriotism and the religious scholars and other orientation bodies must reorient people towards peaceful coexistence among them.

\section{References}

Ango, S. 2001. The Emergence of Ethnic Militias. An unpublished Seminar paper presented at Federal College of Education Zaria.

Adoke, I. 2008. Violence, Conflict, Ethnic Militias and Nigeria Democracy. In, Adeniji A.L. Nigerian Democracy and the Journey So Far. Ibadan: Jilat Publishing Company.

Badsha, M. \& Turaki, A. H. 2012, Daily Trust Newspaper, 24th December.

Bambose, A. 1971. The English Language in Nigeria. In, Spencer (Ed.). The Language in West Africa. Ibadan: University Press.

Babawale T. 2003. Urban Violence, and the Challenges of Democratic Consolidation in Nigeria. Lagos: Malthouse Press Limited.

Bukhari, M. I. 1997. Sahih Al-Bukhari, Arabic-English. Muhsin M. Khan. Saudi Arabia: Darussalam

Bukhari, M. I. 2007. Adab al-Mufrad al-Jami lil Adab al-Nubuwah. npp: np.

Bello, T. \& Stella Oduah. 2013. Tribalism, ethnicity, the bane of Nigeria's development. Vanguard Newspaper. October 28.

Dopamu. A. I. 2010. Religious Pluralism in Nigeria: The Example of the Yoruba. In Ade, P. D. et.al. (eds.). Dialogue. Lagos Big Small Books.

Gender in Nigeria Report 2012: Improving the lives of girls and women in Nigeria.

Ibn Majah, M. 2007. Sunan Ibn Majah. Arabic-English by Nasiruddin al-Khattab Translation. Saudi Arabia: Darussalam

Ideyi \& Isijola. 2007. Theocracy and Conflict Generation in Nigeria. In, Historical Perspective on Nigerian's Post-Colonial Conflict. (ed) Olayemi A. 0.

Oke, M.A. 2008. Multi-Lingualism and National Development: A case study of Arabic. In, Adeniji A. L. Nigerian Democracy and the Journey So Far. Ibadan: Jilat Publishing Company.

Olu, A. 2007. Unemployment crisis at Cross: Nigeria at cross Road?. The Guardian Newspaper. September 18.

Okwudiba, N. 1978. Ethnic Politics in Nigeria, $4^{\text {th }}$ ed. Malta: Interprint Malta Limited.

Popoola J.S. 2014. Multilingualism: A catalyst to National Development. In Clement O. B. The postgraduate Journal of Multidisciplinary Studies Vol. 12. No. 1. Ilorin: Postgraduate School, University of Ilorin.

Robin L. 1971. The Nigerian Military. Cambridge: Cambridge University Press.

Sheha, A. S. 2003. Misconception on Human Rights in Islam, Trans. by M. S. Dabas, $4^{\text {th }}$ ed. Saudi Arabia. n.p.

Syed, S. A. 2008. The Muqaddimah of Ibn Khaldun: Religion, Human Nature And Economics, Malaysia: Selangor International Islamic University College.

Usman, J. M. 2013. Conceptual exposition of poverty and its alleviation in Nigeria from the Islamic perspective. In, Muhammad A. S. Ad-Dirayah International Journal of Islamic Studies. A publication of the Islamic Studies Unit, Department of Religions, Nasarawa State University.Vol. 1. No. 2. 